\title{
Population dynamics of heterotrophic dinoflagellates during a Gymnodinium mikimotoi red tide in the Seto Inland Sea
}

\author{
Yasuo Nakamura ${ }^{1, *}$, Shin-ya Suzuki ${ }^{2}$, Juro Hiromi ${ }^{2}$ \\ ${ }^{1}$ National Institute for Environmental Studies, Tsukuba, Ibaraki 305, Japan \\ ${ }^{2}$ College of Agriculture and Veterinary Medicine, Nihon University, Setagaya, Tokyo 154, Japan
}

\begin{abstract}
Populations of heterotrophic dinoflagellates, phytoplankton and ciliates were monitored daily during summer 1994 in the Seto Inland Sea, Japan. The growth rates of heterotrophic dinoflagellates in screened seawater $(<50 \mu \mathrm{m})$ were also measured. During the survey period, a Gymnodinium mikimotoi red tide occurred, continued for $1 \mathrm{wk}$ and disappeared. Following the outbreak of the red tide, abundance and growth rates of heterotrophic dinoflagellates (mainly composed of Gyrodinium dominans and Gyrodinium spirale) increased rapidly. Calculations of the impact of grazing by the heterotrophic dinoflagellates on the G. mikimotoi red tide strongly suggest that they played an important role in the disappearance of the red tide. On the other hand, the ciliate population (mainly composed of oligotrichs of ca $45 \mu \mathrm{m}$ ) did not respond to the red tide but covaried with the population of small ( 2 to $8 \mu \mathrm{m})$ flagellates, suggesting that ciliates are not direct competitors of heterotrophic dinoflagellates in this region
\end{abstract}

KEY WORDS: Heterotrophic dinoflagellates $\cdot$ Microzooplankton $\cdot$ Red tide $\cdot$ Grazing $\cdot$ Growth

\section{INTRODUCTION}

Heterotrophic dinoflagellates are one of the major components of the microzooplankton in estuarine, oceanic and polar ecosystems (e.g. Smetacek 1981, Nöthig \& von Bodungen 1989, Hansen 1991, Lessard 1991, Verity et al. 1993), and their biomass sometimes exceeds that of planktonic ciliates (summarized by Lessard 1991). Experimental laboratory studies on the range of prey that supports growth, ingestion and growth rates indicate that these organisms are basically herbivorous, ingest prey as large as themselves, and can have a significant impact on phytoplankton populations (e.g. Strom 1991, Hansen 1992, Nakamura et al. 1992, 1995, Jacobson \& Anderson 1993, Strom \& Buskey 1993)

In coastal ecosystems, high abundances of heteratrophic dinoflagellates are often observed during or just after phytoplankton blooms (Jacobson 1987, Han-

•E-mail: yasuo@nies.go.jp sen 1991, Lessard 1991, Nakamura et al. 1992, Jeong \& Latz 1994). However, there have been few field studies dealing with the population dynamics of heterotrophic dinoflagellates throughout a phytoplankton bloom. Thus, for a complete understanding of the trophic roles of heterotrophic dinoflagellates in coastal ecosystems, there is a clear need to examine how their populations develop throughout the phytoplankton-blooming period by frequently monitoring their abundance and measuring the growth rates of natural populations.

Red tides of Gymnodinium mikimotoi (equivalent spherical diameter, ESD $=16.8 \mu \mathrm{m}$ for strain NIES 249 isolated from the Seto Inland Sea, Japan; Nakamura et al. 1995) often occur during the warm season in the Seto Inland Sea. The abundance of a heterotrophic dinoflagellate, Gyrodinium dominans $(\mathrm{ESD}=20.8 \mu \mathrm{m}$ for strain Harima; Nakamura et al. 1995), drastically increases (>100 $\mathrm{ml}^{-1}$ in some cases) during the collapse of such red tides ( $\mathrm{H}$. Takayama pers. comm.). Furthermore, our laboratory culture experiments indicate that $G$. dominans prefer particles of a size similar 
to that of $G$. mikimotoi cells and these grazers can play a significant role in the collapse of $G$. mikimotoi red tides (Nakamura et al. 1995). Therefore, the abundance of heterotrophic dinoflagellates, with special reference to $G$. dominans, was monitored, along with those of ciliates (a potential competitor of heterotrophic dinoflagellates), phytoplankton in various taxa (see Table 1), bacteria, and heterotrophic nanoflagellates (HNF), throughout the outbreak period of a $G$. mikimotoi red tide in the Seto Inland Sea. We also measured the growth rates of natural populations of heterotrophic dinoflagellates using a size fractionation approach. In the present paper we describe the results obtained in the field survey and field experiments designed to clarify the trophic roles of heterotrophic dinoflagellates in eutrophic coastal ecosystems.

\section{MATERIALS AND METHODS}

Field observations. In summer 1994 (15 July to 8 August), field surveys were conducted at Stn B (34 $35^{\prime} \mathrm{N}$, $134^{\circ} 30^{\prime} \mathrm{E}, 21 \mathrm{~m}$ depthi see Nakamura et al. 1993) around the Ie-shima Islands in the Seto Inland Sea. Temperature, salinity, dissolved oxygen, nutrients and chlorophyll a (chl a) were monitored daily. Analytical procedures and the results of these analyses will be summarized elsewhere (Ichimi et al. unpubl.). Samples for plankton enumeration were taken daily (06:20 to $07: 30 \mathrm{~h}$ ) from depths of 0 and $10 \mathrm{~m}$ using a Van Dorntype bottle. The samples $(80 \mathrm{ml})$ were fixed immediately with glutaraldehyde (EM-grade, final conc. $1 \%$ ), stored at $5^{\circ} \mathrm{C}$ for $1 \mathrm{~h}$ and stained with DAPI (final conc. $1 \mu \mathrm{g} \mathrm{ml}^{-1}$; Porter \& Feig 1980). Then subsamples of 3 or $20 \mathrm{ml}$ were concentrated onto 0.2 or $0.8 \mu \mathrm{m}$ pore size black Nuclepore filters under low ( $<100 \mathrm{~mm} \mathrm{Hg}$ ) vacuum. These filters were observed with Nikon epifluorescence microscopes equipped with $\mathrm{Hg} 100 \mathrm{~W}$ lamps and the appropriate exciter/barrier filter sets for UV (330 to $380 \mathrm{~nm}$ ) and blue ( 450 to $490 \mathrm{~nm}$ ) excitation. Conditions for enumeration of each plankton category are summarized in Table 1 Autotrophic and heterotrophic cells were identified by the presence or absence of autofluorescent chloroplasts. Dinoflagellates were distinguished from other flagellates based upon morphology and structure of the nucleus, especially the unique condensed chromosomes visible with DAPI staining, and cell morphology (cf. Verity et al. 1993). Since we were especially interested in the dynamics of Gyrodinium dominans, $G$. dominans-like particles (GDLP) were enumerated separately from other heterotrophic dinoflagellates based on cell size and

Table 1. Planktonic taxa enumerated and conditions for enumeration. V volume of sample filtered; Mag: magnification. A: autotrophic; $\mathrm{H}$ : heterotrophic $\mathrm{M}$ : mixotrophic. K: number of fields observed; DL: detection limit. GDLP: Gyrodinium dominans-like particles

\begin{tabular}{|c|c|c|c|c|c|c|c|}
\hline Length ( $\mu \mathrm{m})$ & $V(\mathrm{ml})$ & $\mathrm{Mag}$ & $\mathrm{A} / \mathrm{H} / \mathrm{M}$ & Category & Field $(\mu \mathrm{m})$ & K & $\mathrm{DL}\left(\mathrm{ml}^{-1}\right)$ \\
\hline $0.2-2$ & 3 & 1250 & $\begin{array}{l}\mathrm{A} \\
\mathrm{A} \\
\mathrm{H}\end{array}$ & $\begin{array}{l}\text { Picocyanobacteria } \\
\text { Eukaryotic picoalgae } \\
\text { Bacteria }\end{array}$ & $\begin{array}{r}80 \times 80 \\
80 \times 80 \\
8 \times 80\end{array}$ & $\begin{array}{l}20 \\
30 \\
20\end{array}$ & $\begin{array}{l}7 \times 10^{2} \\
7 \times 10^{2} \\
7 \times 10^{3}\end{array}$ \\
\hline $2-8$ & 20 & 1250 & $\begin{array}{l}\mathrm{A} \\
\mathrm{H}\end{array}$ & $\begin{array}{l}\text { Nanoplankton } \\
\text { Nanoflagellates }\end{array}$ & $\begin{array}{l}80 \times 80 \\
80 \times 80\end{array}$ & $\begin{array}{l}40 \\
40\end{array}$ & $\begin{array}{l}5 \times 10^{1} \\
5 \times 10^{1}\end{array}$ \\
\hline $8-20$ & 20 & 500 & $\begin{array}{l}\mathrm{A} \\
\mathrm{H} \\
\mathrm{H}\end{array}$ & $\begin{array}{l}\text { Nanoflagellates } \\
\text { Dinoflagellates } \\
\text { Ciliates }\end{array}$ & $\begin{array}{l}200 \times 200 \\
200 \times 200 \\
200 \times 200\end{array}$ & $\begin{array}{l}200 \\
200 \\
200\end{array}$ & $\begin{array}{l}2 \times 10^{0} \\
2 \times 10^{0} \\
2 \times 10^{0}\end{array}$ \\
\hline $16-40$ & 20 & 250 & $\mathrm{H}$ & GDLP & $400 \times 400$ & 200 & $4 \times 10^{-1}$ \\
\hline $20-40$ & 20 & 200 & $\begin{array}{l}A \\
A \\
A \\
A \\
A\end{array}$ & $\begin{array}{l}\text { Naked dinoflagellates } \\
\text { Thecate dinoflagellates } \\
\text { Naked flagellates }^{\text {a }} \\
\text { Silicoflagellates } \\
\text { Mesodinium rubrum }\end{array}$ & $\begin{array}{l}970 \varnothing \\
970 \varnothing \\
970 \varnothing \\
970 \varnothing \\
970 \varnothing\end{array}$ & $\begin{array}{l}100 \\
100 \\
100 \\
100 \\
100\end{array}$ & $\begin{array}{l}2 \times 10^{-1} \\
2 \times 10^{-1} \\
2 \times 10^{-1} \\
2 \times 10^{-1} \\
2 \times 10^{-1}\end{array}$ \\
\hline & & 250 & $\begin{array}{l}\mathrm{H} \\
\mathrm{H} \\
\mathrm{M} / \mathrm{H}\end{array}$ & $\begin{array}{l}\text { Naked dinoflagellates } \\
\text { Thecate dinoflagellates } \\
\text { Naked ciliates }\end{array}$ & $\begin{array}{l}400 \times 400 \\
400 \times 400 \\
400 \times 400\end{array}$ & $\begin{array}{l}200 \\
200 \\
200\end{array}$ & $\begin{array}{l}4 \times 10^{-1} \\
4 \times 10^{-1} \\
4 \times 10^{-1}\end{array}$ \\
\hline $40-200$ & 20 & 200 & $\begin{array}{c}\text { A } \\
\mathrm{A} \\
\mathrm{A} \\
\mathrm{H} \\
\mathrm{H} \\
\mathrm{M} / \mathrm{H} \\
\mathrm{H}\end{array}$ & $\begin{array}{l}\text { Naked dinoflagellates } \\
\text { Thecate dinoflagellates } \\
\text { Naked flagellates } \\
\text { Naked dinoflagellates } \\
\text { Thecate dinoflagellates } \\
\text { Naked ciliates } \\
\text { Tintinnids }\end{array}$ & $\begin{array}{l}970 \varnothing \\
970 \varnothing \\
970 \varnothing \\
970 \varnothing \\
970 \varnothing \\
970 \varnothing \\
970 \varnothing\end{array}$ & $\begin{array}{l}100 \\
100 \\
100 \\
130 \\
130 \\
130 \\
130\end{array}$ & $\begin{array}{l}2 \times 10^{-1} \\
2 \times 10^{-1} \\
2 \times 10^{-1} \\
1 \times 10^{-1} \\
1 \times 10^{-1} \\
1 \times 10^{-1} \\
1 \times 10^{-1}\end{array}$ \\
\hline
\end{tabular}


shape. Ciliates were distinguished from other protozoa by shape, the presence of cilia, and the presence of multiple dimorphic nuclei (cf. Sherr et al. 1986). The autotrophic ciliate Mesodinium rubrum was counted separately. Counting was carried out on the same day the samples were collected. Since species identification of naked heterotrophic dinoflagellates is difficult by observation of fixed and stained cells under epifluorescent microscopes, live samples (usually $0.5 \mathrm{ml} \times$ 3 per sample) were also observed with an inverted microscope (including epifluorescence optics) to identify the dominant species of heterotrophic dinoflagellates. The abundance of Gymnodinium mikimotoi after 24 July in samples from depths of $0,5,10,15$ and $19 \mathrm{~m}$ was enumerated by observing $1 \mathrm{ml}$ of each live sample under a light microscope.

Growth experiments. Microzooplankton growth experiments with seawater prescreened through a $50 \mu \mathrm{m}$ sieve were conducted 9 times. Seawater was collected from 0,5 or $10 \mathrm{~m}$ (depending on sampling date; see Table 3 ) in the morning during routine sampling, poured into a 21 polypropylene bottle, and returned to our field laboratory within $15 \mathrm{~min}$ of sampling. The samples were stored for $1 \mathrm{~h}$ in an incubator $\left(25^{\circ} \mathrm{C}\right.$, ca $25 \mu \mathrm{E} \mathrm{m} \mathrm{m}^{-2} \mathrm{~s}^{-1}$ illumination) and filtered through a $50 \mu \mathrm{m}$ sieve. Then $500 \mathrm{ml}$ of filtrate was dispensed into each of 2 pre-sterilized 11 Erlenmeyer flasks which had been rinsed several times with the filtrates. Those flasks were incubated for ca $24 \mathrm{~h}$ under the conditions described above with a $12 \mathrm{~h}$ light: $12 \mathrm{~h}$ dark cycle. For plankton enumeration, an initial sample $(80 \mathrm{ml})$ was taken from the $<50 \mu \mathrm{m}$ filtrate and final samples were taken from each flask at the end of incubation. These samples were fixed, stained and enumerated for each plankton taxon (Table 1). Samples were also taken for identification of the dominant heterotrophic dinoflagellates (see 'Field observations'). The filtration process eliminated the metazooplanktons effectively and did not seem to cause any damage to fragile species such as Gymnodinium mikimotoi and
Gyrodinium dominans as was confirmed by the observations of live and stained samples under microscopes. Growth rates were calculated for each taxon for which the total counts in the initial sample exceeded 10. These growth rates were calculated by $\mu=\ln \left(N_{1} / N_{i}\right) / T$, where $N_{1}$ and $N_{f}$ are the initial and final concentrations and $T$ is the incubation time

\section{RESULTS}

The weather was sunny, calm and very hot throughout the survey period, except from 24 to 26 July when strong wind due to a typhoon blew continuously and some precipitation was recorded. Surface water temperatures (Fig. 1) were 2 to $3^{\circ} \mathrm{C}$ higher than those recorded during previous years (cf. Nakamura \& Umemori 1991, Nakamura et al. 1993). Salinity ranged from 31.9 to $32.3 \%$ at the surface and from 32.4 to $33.1 \%$ at $20 \mathrm{~m}$. Nitrate concentrations $\left(\mathrm{S}_{\mathrm{NO}_{3}}\right)$ at the surface were very low $(<0.1 \mu \mathrm{M})$ as was the case during previous years when the water column was thermally stratified. $S_{\mathrm{NO}_{3}}$ at $10 \mathrm{~m}$ never exceeded $1 \mu \mathrm{M}$ and this was very unusual for this area during summer (cf. Nakamura \& Umemori 1991, Nakamura et al. 1993). Although enumerations were not conducted, diatoms (Chaetoceros spp.) were abundant from 15 to 24 July. Their abundance seemed to decrease and the red autofluorescence from their chloroplasts weakened towards 24 July. The abundance of naked autotrophic dinoflagellates (NAD) from 20 to $40 \mu \mathrm{m}$ in size (mainly composed of Gymnodinium mikimotoi) was less than $10 \mathrm{ml}^{-1}$ until 24 July (Fig. 2). However, on 22 July the seawater in a small fishing port (ca $5 \mathrm{~m}$ depth, 2 ha area, about $2 \mathrm{~km}$ from $\mathrm{Stn}$ B) was discolored by $G$. mikimotoi $\left(1500 \mathrm{ml}^{-1}\right)$. On $25 \mathrm{July}$, the abundance of $G$. mikimotoi exceeded $10 \mathrm{ml}^{-1}$ at depths between 5 and $15 \mathrm{~m}$, reaching a maximum $\left(30 \mathrm{ml}^{-1}\right)$ at $15 \mathrm{~m}$. On 26 July, a $G$. mikimotoi red tide occurred suddenly. The abundance of NAD with sizes of 20 to $40 \mu \mathrm{m}$ (average
Fig. 1. Temporal changes in water temperature in the Seto Inland Sea, Japan, 1994.

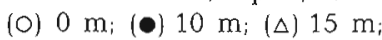
(A) $20 \mathrm{~m}$

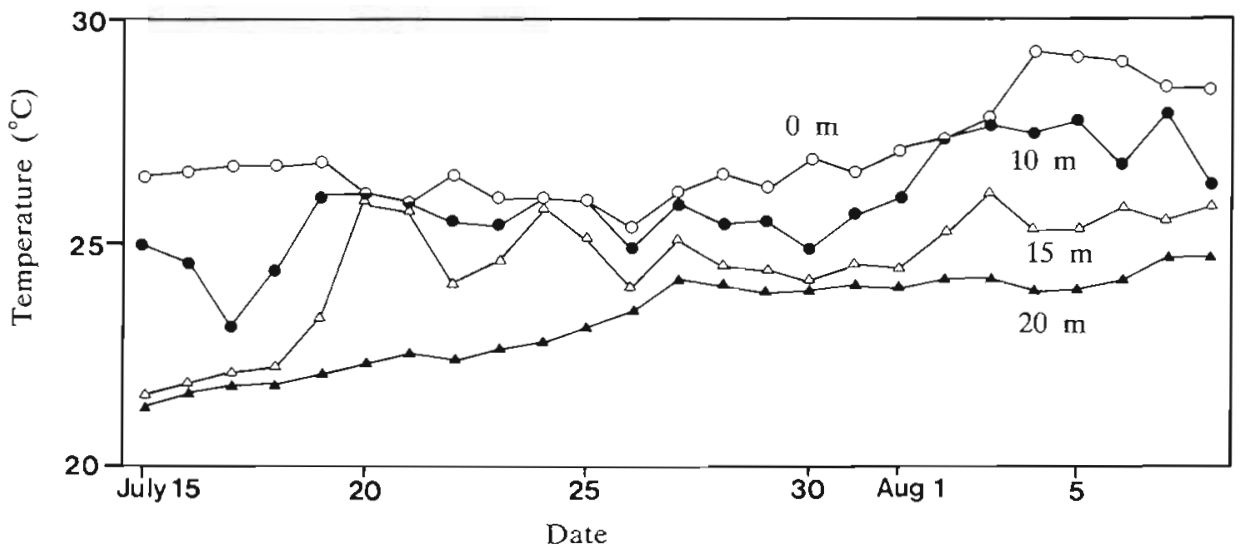




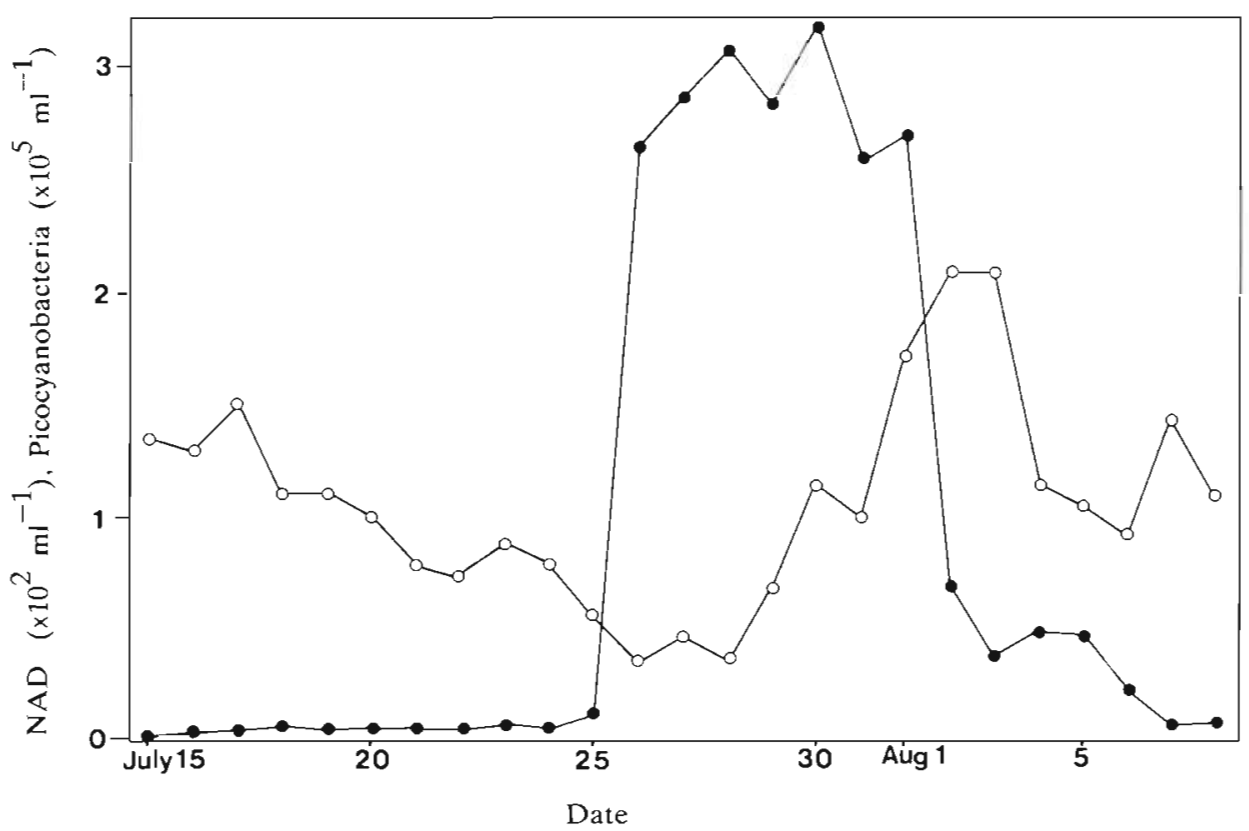

Fig. 2. Temporal changes in the abundance of ( $)$ naked autotrophic dinoflagellates (NAD; 20 to $40 \mu \mathrm{m}$ ) and (O) picocyanobacteria; averages of values for 0 and $10 \mathrm{~m}$ of the values for 0 and $10 \mathrm{~m}$ ) was 250 to $320 \mathrm{ml}^{-1}$ from 26 July to 1 August, decreased suddenly on 2 August, and returned to a 'normal' level by 7 August (Fig. 2).

Table 2. Abundance of planktonic taxa. GDLP: Gyrodinium dominanslike particles

\begin{tabular}{|c|c|c|c|}
\hline & \multirow[t]{2}{*}{ Size $(\mu \mathrm{m})$} & \multicolumn{2}{|c|}{ Abundance $\left(\mathrm{ml}^{-1}\right)$} \\
\hline & & Range & Average \\
\hline \multicolumn{4}{|l|}{ Autotrophs } \\
\hline Picocyanobacteria & $0.2-2$ & $(0.3-2.2) \times 10^{5}$ & $1.0 \times 10^{5}$ \\
\hline Eukaryotic picoalgae & $0.2-2$ & $(0.5-18) \times 10^{3}$ & $4.0 \times 10^{3}$ \\
\hline Nanoplankton & $2-8$ & $(1.0-4.1) \times 10^{3}$ & $2.2 \times 10^{3}$ \\
\hline Nanoflagellates & $8-20$ & $(2.1-19) \times 10^{1}$ & $6.9 \times 10^{1}$ \\
\hline Naked dinoflagellates & $20-40$ & $(0.1-45) \times 10^{1}$ & $8.9 \times 10^{1}$ \\
\hline Thecate dinoflagellates & $20-40$ & $(<0.2-5.6) \times 10^{0}$ & $1.0 \times 10^{0}$ \\
\hline Naked flagellates $^{\circ}$ & $20-40$ & $(<0.2-2.5) \times 10^{0}$ & $0.9 \times 10^{0}$ \\
\hline Silicoflagellates & $20-40$ & $(<0.2-0.4) \times 10^{0}$ & $<0.2 \times 10^{0}$ \\
\hline Mesodinium rubrum & $>20$ & $(<0.2-1.2) \times 10^{0}$ & $0.3 \times 10^{0}$ \\
\hline Naked dinoflagellates & $40-200$ & $(<0.2-1.1) \times 10^{0}$ & $0.2 \times 10^{0}$ \\
\hline Thecate dinoflagellates & $40-200$ & $(<0.2-2.1) \times 10^{0}$ & $0.6 \times 10^{0}$ \\
\hline Naked flagellates $^{a}$ & $40-200$ & $(<0.2-1.1) \times 10^{0}$ & $0.4 \times 10^{0}$ \\
\hline \multicolumn{4}{|l|}{ Heterotrophs } \\
\hline Bacteria & $0.2-2$ & $(2.1-4.3) \times 10^{6}$ & $3.0 \times 10^{6}$ \\
\hline Nanoflagellates & $2-8$ & $(0.4-5.8) \times 10^{3}$ & $2.1 \times 10^{3}$ \\
\hline Dinoflagellates ${ }^{b}$ & $8-20$ & $(0.3-4.1) \times 10^{1}$ & $1.7 \times 10^{1}$ \\
\hline Ciliates & $8-20$ & $(<2-10) \times 10^{0}$ & $2.2 \times 10^{0}$ \\
\hline GDLP & $16-40$ & $(0.04-3.1) \times 10^{1}$ & $1.1 \times 10^{1}$ \\
\hline Naked dinoflagellates ${ }^{b}$ & $20-40$ & $(<0.4-6.0) \times 10^{0}$ & $2.9 \times 10^{0}$ \\
\hline Thecate dinoflagellates & $20-40$ & $(<0.4-2.0) \times 10^{0}$ & $<0.4 \times 10^{0}$ \\
\hline Naked ciliates & $20-40$ & $(<0.4-9.8) \times 10^{9}$ & $1.5 \times 10^{\circ}$ \\
\hline Naked dinoflagellates & $40-200$ & $(0.2-9.2) \times 10^{0}$ & $2.3 \times 10^{0}$ \\
\hline Thecate dinoflagellates & $40-200$ & $(<0.1-1.0) \times 10^{0}$ & $0.2 \times 10^{0}$ \\
\hline Naked ciliates & $40-200$ & $(0.1-2.1) \times 10^{0}$ & $0.9 \times 10^{0}$ \\
\hline Tintinnids & $>40$ & $(<0.1-0.2) \times 10^{0}$ & $<0.1 \times 10^{\circ}$ \\
\hline
\end{tabular}

During the first half of the outbreak (26 to 28 July), $G$. mikimotoi seemed active: the cells showed bright autofluorescence and were most abundant near the surface $(0$ to $5 \mathrm{~m})$ in the morning. Furthermore, a dense accumulation of $G$. mikimotoi at the surface was observed around noon (ca $2000 \mathrm{ml}^{-1}$; Ichimi et al. unpubl.). In contrast, from 29 July to 1 August, the autofluorescence weakened, the layer of maximum abundance in the morning shifted to $10 \mathrm{~m}$ and accumulation at the surface around noon was not observed.

The temporal changes in the abundances of autotrophic plankton taxa (Table 2) exhibited no systematic trends except those for picocyanobacteria and NAD (20 to $40 \mu \mathrm{m})$. The abundance of picocyanobacteria decreased gradually from 15 to 28 July, then increased rapidly, reaching a maximum $(2 \times$ $10^{5} \mathrm{ml}^{-1}$ ) on 2 and 3 August, and then decreased again (Fig. 2). It should also be noted that the abundance of picocyanobacteria in 1994 was about 1 order of magnitude higher than that observed during previous years (cf. Nakamura et al. 1993).

Coupled with the outbreak of the red tide, chl a increased rapidly and reached a peak on 28 July (Fig. 3). Then it decreased sharply from 28 to 31 July while Gymnodinium mikimotoi was still abundant (cf. Fig. 2). This was probably due to the decrease in chl a per $G$. mikimotoi cell as confirmed by the epifluorescent microscope observations (see 'Materials and methods'). The abundances of 
Fig. 3. Temporal changes in (0) chl $a_{1}$ and abundances of $(\bullet)$ bacteria and $(\Delta)$ heterotrophic nanoflagellates (HNF; 2 to $8 \mu \mathrm{m}$ ); averages of values for 0 and $10 \mathrm{~m}$. Note difference in bacteria scale

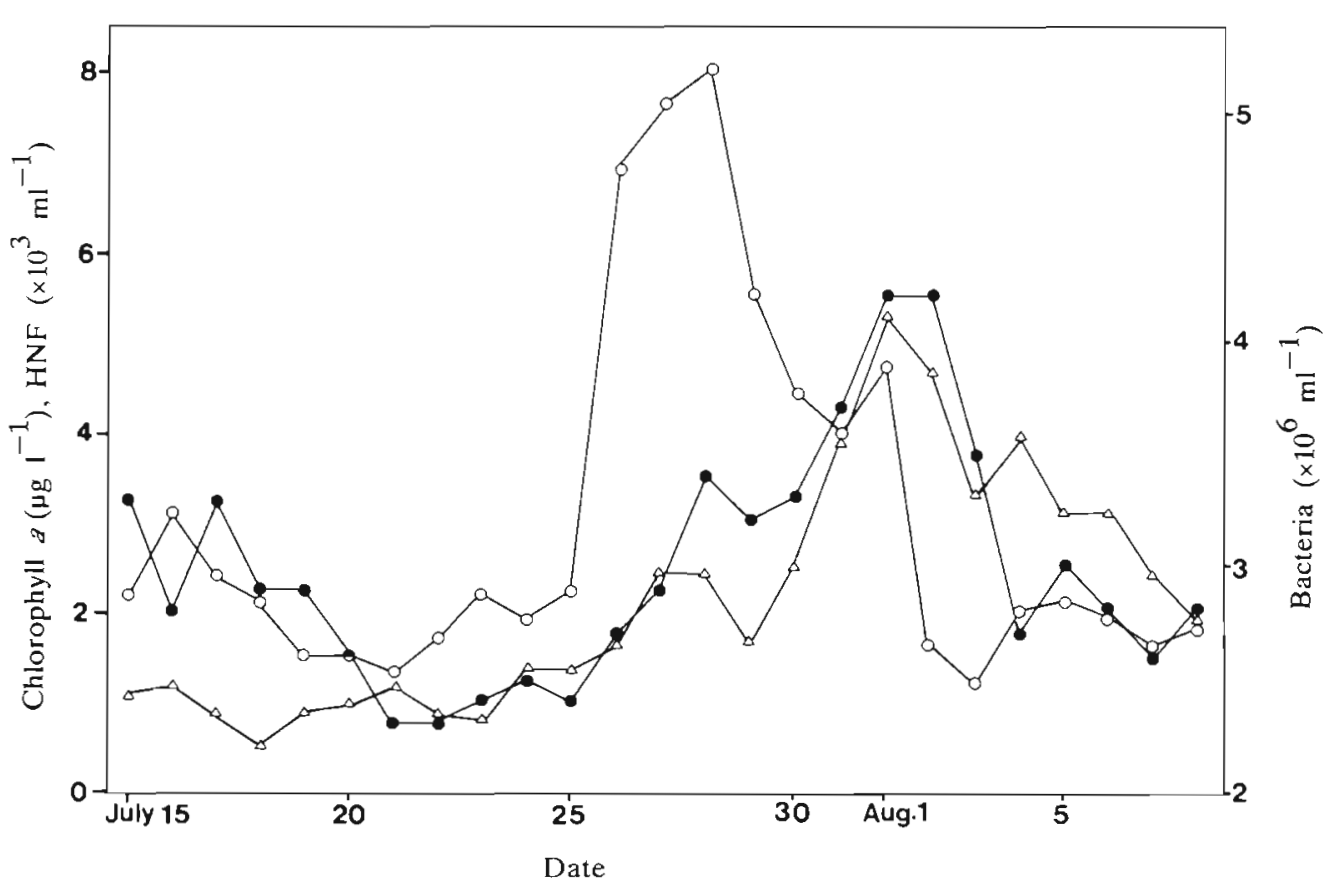

bacteria and heterotrophic nanoflagellates (HNF) with sizes of 2 to $8 \mu \mathrm{m}$ increased following the bloom (Fig. 3), suggesting strong coupling between phytoplankton (excreted organic materials) and bacteria and HNF (Nakamura et al. 1994).

GDLP and naked heterotrophic dinoflagellates (NHD) larger than $40 \mu \mathrm{m}$ responded dramatically to the bloom (Fig. 4). The abundance of GDLP was less than $5 \mathrm{ml}^{-1}$ before the outbreak of Gymnodinium mikimotoi (except on 18 and 25 July). GDLP abundance started to increase 1 or $2 \mathrm{~d}$ after the outbreak and sustained high values $\left(>10 \mathrm{ml}^{-1}\right.$ ) from 29 July (middle of the red tide period) to 7 August ( $5 \mathrm{~d}$ after the disappearance of the red tide). Observations of the live samples confirmed the propagation of Gyrodinium dominans following the start of the red tide. The abundance
Fig. 4. Temporal changes in the abundances of (o) naked autotrophic flagellates (NAF; 20 to $40 \mu m_{i}$ including dinoflagellates), (•) Gyrodinium dominans-like particles (GDLP) and $(\Delta)$ naked heterotrophic dinoflagellates (NHD; $>40 \mu \mathrm{m}$ ); averages of values for 0 and $10 \mathrm{~m}$. Note difference in NHD scale

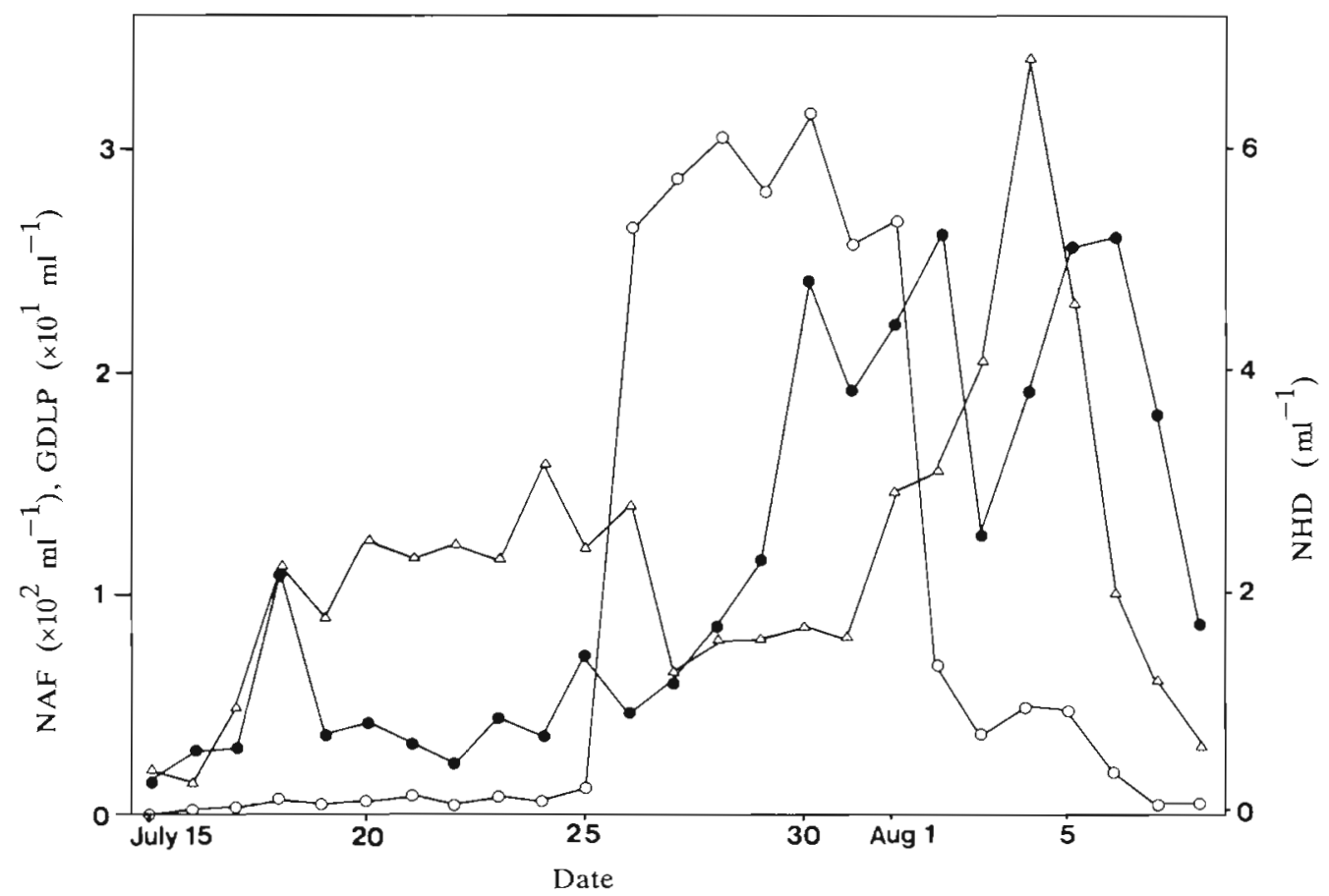




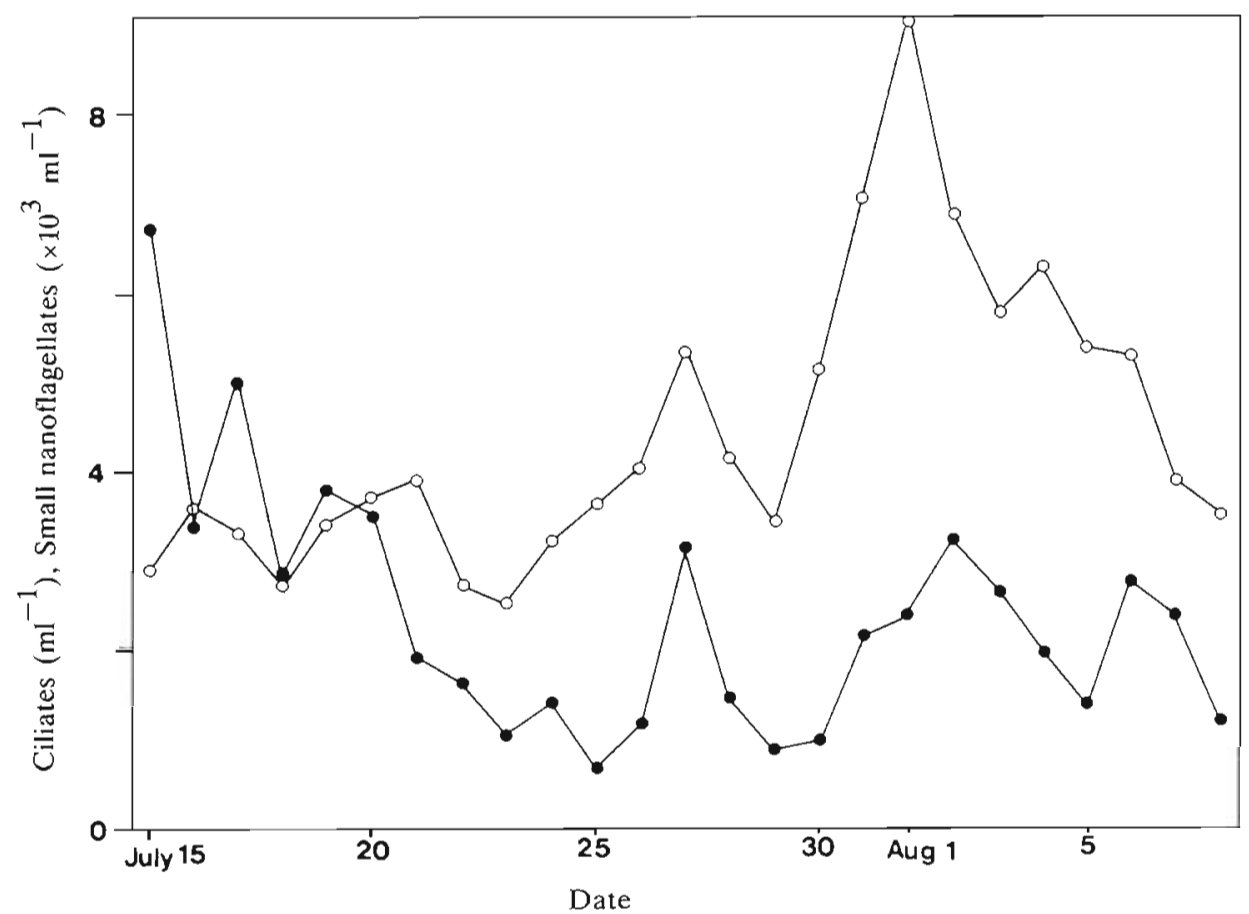

Fig. 5. Temporal changes in the abundances of $(\bullet$ naked ciliates $(>20 \mu \mathrm{m})$ and (O) small nanoflagellates 12 to $8 \mu \mathrm{m}$, autotrophic plus heterotrophic); averages of values for 0 and $10 \mathrm{~m}$

of $\mathrm{NHD}(>40 \mu \mathrm{m})$ before the outbreak was relatively constant (2.4 to $3.2 \mathrm{ml}^{-1}$ from 18 to $25 \mathrm{July}$ ). It then decreased on $27 \mathrm{July}$, remained constant $\left(1.5 \mathrm{ml}^{-1}\right)$ until 31 July (the latter half of the red tide), increased rapidly to reach a maximum $\left(6.8 \mathrm{ml}^{-1}\right)$ on 4 August, and finally decreas-ed sharply. Observations of live samples indicate a species succession among the NHD $(>40 \mu \mathrm{m})$ population. Until $30 \mathrm{July}$, the dominant species was Gyrodinium fusiforme and/or Nematodinium armatum and Gyrodinium spirale comprised $<1 / 3$ of the total NHD (>40 $\mu \mathrm{m})$ cell number. After 1 August, $G$. spirale became dominant, contributing about $80 \%$ of NHD $(>40 \mu \mathrm{m})$ cell number. During the red tide, about
$20 \%$ of the GDLP and NHD $(>40 \mu \mathrm{m})$ cells had a food vacuole $(>10 \mu \mathrm{m})$ which showed red autofluoresence and in some cases had dinoflagellate nuclei probably originating from $G$. mikimotoi cells. After the red tide, GDLP and NHD (>40 $\mu \mathrm{m})$ occasionally contained food vacuoles originating from clumps of picocyanobacteria or amorphous materials that fluoresced yellow upon UV excitation. The abundances of other categories of heterotrophic dinoflagellates (Table 2) did not show any systematic trends.

Ciliates smaller than $20 \mu \mathrm{m}$ were always less abundant than $10 \mathrm{ml}^{-1}$ and did not show any trends. Tintinnids were rarely observed throughout the survey

Table 3. Experimental conditions and growth rates of heterotrophic dinoflagellates and ciliates in prescreened seawater. ANP: autotrophic nanoplankton; HNF: heterotrophic nanoflagellates. NAF: naked autotrophic flagellates (dinoflagellates plus other flagellates); GDLP: Gyrodinium dominans-like particles; NHD: naked heterotrophic dinoflagellates; CIL: ciliates. \pm : range of values obtained in 2 experimental flasks. nc: not calculated

\begin{tabular}{|c|c|c|c|c|c|c|c|}
\hline \multirow[t]{2}{*}{ Expt } & \multirow[t]{2}{*}{ Date } & \multirow[t]{2}{*}{ Source $(\mathrm{m})$} & \multicolumn{2}{|c|}{ Initial abundance $\left(\mathrm{ml}^{-1}\right)$} & \multicolumn{3}{|c|}{ Growth rates $\left(\mathrm{d}^{-1}\right)$} \\
\hline & & & $\begin{array}{c}\text { ANP + HNF } \\
(2-8 \mu \mathrm{m})\end{array}$ & $\begin{array}{c}\text { NAF } \\
(20-40 \mu \mathrm{m})\end{array}$ & GDLP & $\begin{array}{c}\text { NHD } \\
(>40 \mu \mathrm{m})\end{array}$ & $\begin{array}{c}\text { CIL } \\
(>20 \mu \mathrm{m})\end{array}$ \\
\hline 1 & 16-17 July & 0 & $2.7 \times 10^{3}$ & $2.8 \times 10^{\circ}$ & $\mathrm{nc}$ & $\mathrm{nc}$ & $-0.21 \pm 0.17$ \\
\hline 2 & $19-20$ July & 0 & $4.2 \times 10^{3}$ & $3.8 \times 10^{0}$ & $\mathrm{nc}$ & $0.33 \pm 0.29$ & $0.51 \pm 0.11$ \\
\hline 3 & $22-23$ July & 0 & $2.0 \times 10^{3}$ & $2.3 \times 10^{0}$ & nc & $-0.03 \pm 0.03$ & ne \\
\hline 4 & $25-26$ July & 0 & $3.5 \times 10^{3}$ & $6.3 \times 10^{0}$ & nc & $0.15 \pm 0.06$ & nc \\
\hline 5 & $28-29$ July & 0 & $3.7 \times 10^{3}$ & $6.8 \times 10^{2}$ & $0.98 \pm 0.12$ & nc & nc \\
\hline 6 & $30-31$ July & 5 & $6.1 \times 10^{3}$ & $2.9 \times 10^{2}$ & $0.86 \pm 0.13$ & $0.61 \pm 0.13$ & nc \\
\hline 7 & 1-2 August & 0 and $10(1: 1)$ & $8.9 \times 10^{3}$ & $2.5 \times 10^{2}$ & $0.06 \pm 0.07$ & $1.30 \pm 0.09$ & $0.86 \pm 0.06$ \\
\hline 8 & $3-4$ August & 0 and $10 \quad(1: 1)$ & $6.1 \times 10^{3}$ & $3.4 \times 10^{1}$ & $-0.43 \pm 0.01$ & $-0.14 \pm 0.19$ & $-0.52 \pm 0.00$ \\
\hline 9 & 6-7 August & 0 and $10(1: 1)$ & $5.1 \times 10^{3}$ & $2.0 \times 10^{1}$ & $-0.01 \pm 0.01$ & $-0.85 \pm 0.15$ & $0.29 \pm 0.29$ \\
\hline
\end{tabular}


period (Table 2). Among naked ciliates ( $>20 \mu \mathrm{m}$ ), oligotrichs between 35 and $50 \mu \mathrm{m}$ in size were most abundant ( $>70 \%$ by number), 60 to $90 \%$ of which were heterotrophic. Throughout the red tide, ciliate cells with food vacuoles $(>10 \mu \mathrm{m})$ fluorescing red were not observed. The abundance of naked ciliates $(>20 \mu \mathrm{m})$ changed in phase with that of 2 to $8 \mu \mathrm{m}$ small flagellates (autotrophic and heterotrophic) from $25 \mathrm{July}$ to 5 August (Fig, 5; $r=0.67$ ).

During the red tide, the growth rates of GDLP and NHD larger than $40 \mu \mathrm{m}$ in the prescreened seawater $\left(<50 \mu \mathrm{m}\right.$ ) were high (Table $3 ;>0.6 \mathrm{~d}^{-1}$, except for GDLP in Expt 7). Before the red tide outbreak (15 to 25 July) and after its disappearance ( 3 to 8 August), the growth rates of GDLP and NHD $(>40 \mu \mathrm{m})$ were low $\left(<0.33 \mathrm{~d}^{-1}\right)$ and negative values were often observed. Systematic trends between the growth rates of ciliates $(>20 \mu \mathrm{m})$ and the abundance of small flagellates ( 2 to $8 \mu \mathrm{m}$ ) were not observed.

\section{DISCUSSION}

The present study provides the first direct measurements of population development and the growth rates of natural populations of heterotrophic dinoflagellates throughout the initiation, development and decline of a red tide. Our results strongly suggest that Gyrodinium dominans and $G$. spirale grew rapidly by ingesting Gymnodinium mikimotoi and that these heterotrophic dinoflagellates play important roles in the disappearance of red tides.

Although a buildup of Gymnodinium mikimotoi was observed on 22 July in a small fishing port, at our sampling station the red tide occurred suddenly on 26 July. Since strong easterly winds blew continuously from 24 to 26 July, one might consider that the red tide was due to advection. However, the abundance of $G$. mikimotoi east of the Ie-shima Islands (samples taken at 6 stations on 25 July from 0 and $5 \mathrm{~m}$ below the surface and $1 \mathrm{~m}$ above the bottom) was below $30 \mathrm{ml}^{-1}$ (except $210 \mathrm{ml}^{-1}$ at $5 \mathrm{~m}$ at the third most distant station, $20 \mathrm{~km}$ away from our station) (S. Nagai et al. pers. comm.). Thus advection alone does not seem to explain the bloom outbreak.

Our laboratory study (Nakamura et al. 1995) indicates that, when fed Heterocapsa triquetra (ESD = $15.3 \mu \mathrm{m}$; comparable to Gymnodinium mikimotoi), the growth rate of Gyrodinium dominans reached a maximum $\left(0.8 \mathrm{~d}^{-1}\right)$ at the prey level of $400 \mathrm{ml}^{-1}$, was about $60 \%$ of the maximum at $100 \mathrm{ml}^{-1}$, and negative below $40 \mathrm{ml}^{-1}$. These results are consistent with those of our field experiments (Table 3 ): the growth rates of GDLP showed high values (except for Expt 7) during the red tide and became negative after the disappearance of the red tide. Thus, based on the results of our labora- tory and field experiments, along with the observation that large food vacuoles ( $>10 \mu \mathrm{m}$ ) probably originating from $G$. mikimotoi were often observed in GDLP, we conclude that the population of $G$. dominans was released from food limitation following the outbreak of the red tide, then increased in abundance.

The dominant species of NHD larger than $40 \mu \mathrm{m}$ after 1 August was Gyrodinium spirale. Although $G$. spirale isolated from the Kattegat, Denmark, were unable to sustain growth below a threshold of ca $1 \times$ $10^{3}$ Heterocapsa triquetra cells $\mathrm{ml}^{-1}$ (Hansen 1992), the growth rates of NHD $(>40 \mu \mathrm{m})$ in this study were higher than $0.6 \mathrm{~d}^{-1}$ when the abundance of Gymnodinium mikimotoi was (2-3) $\times 10^{2} \mathrm{ml}^{-1}$ (Table 3); moreover some NHD $(>40 \mu \mathrm{m})$ in the natural population contained vacuoles probably originating from G. mikimotoi. These results indicate that NHD $(>40 \mu \mathrm{m})$ increased in abundance by consuming G. mikimotoi cells during the red tide.

Since ciliates are considered potential competitors of heterotrophic dinoflagellates (cf. Lessard 1991), the biomasses of the 2 groups were compared (Fig. 6). The biomass of ciliates was much lower than that of heterotrophic dinoflagellates except from 15 to 20 July. The biomass of $<20 \mu \mathrm{m}$ ciliates and $<20 \mu \mathrm{m}$ heterotrophic dinoflagellates made up less than 13\% (averages $6 \%$ and $5 \%$, respectively) of the total biomass for each group. The contributions of GDLP and NHD $(>40 \mu \mathrm{m})$ to the total biomass of heterotrophic dinoflagellates were over $57 \%$ (avg $77 \%$ ) throughout the survey period and exceeded $84 \%$ after $29 \mathrm{July}$.

Abundance and biomass of ciliates did not respond to the outbreak of the Gymnodinium mikimotoi red tide (Figs. $2 \& 5$ ), and no large food vacuoles (>10 $\mu \mathrm{m}$ ) with red autofluorescence were observed inside ciliate cells. Furthermore, the abundance of ciliates covaried with that of small ( 2 to $8 \mu \mathrm{m}$ ) nanoflagellates from 25 July to 5 August (Fig. 5) and Gyrodinium dominans cannot utilize small flagellates effectively (Nakamura et al. 1995). These results suggest that the ciliates could not utilize $G$. mikimotoi as a food, fed on other food sources (probably small nanoflagellates), and did not compete with $G$. dominans and $G$. spirale.

In order to assess whether ingestion by heterotrophic dinoflagellates contributed significantly to the disappearance of the red tide, the impact of Gyrodinium dominans and $G$. spirale grazing on Gymnodinium mikimotoi was estimated. The basic assumptions were (1) the abundances of GDLP and NHD (>40 $\mu \mathrm{m})$ are equal to those of $G$. dominans and $G$. spirale, respectively, (2) ingestion parameters of $G$. dominans fed Heterocapsa triquetra (Nakamura et al. 1995) are applicable to natural populations and (3) the biovolume specific ingestion rates of $G$. spirale (vol $=12000 \mu^{3}$ ) are the same as those of $G$. dominans ( $\mathrm{vol}=4800 \mu \mathrm{m}^{3}$ ). 


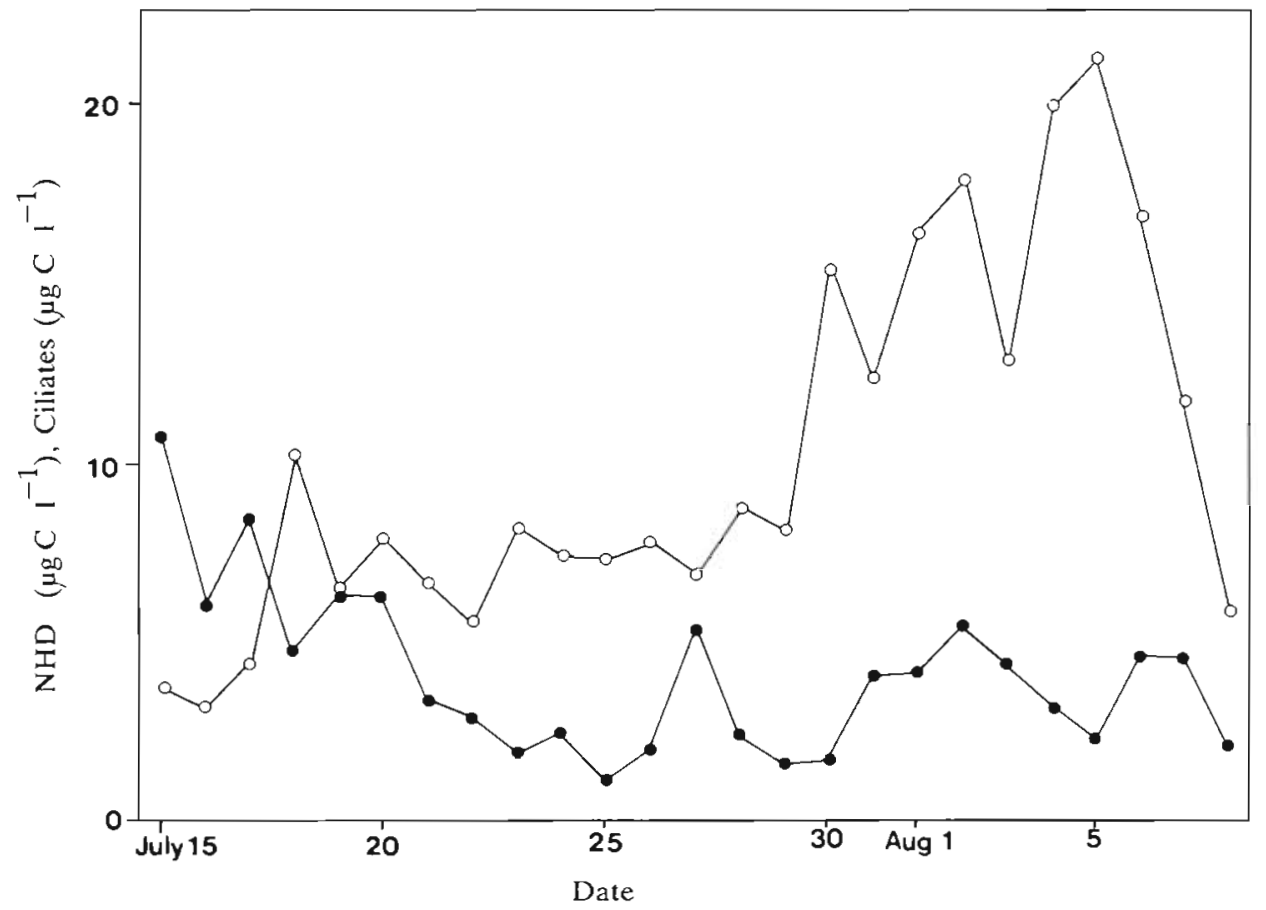

Fig. 6. Temporal changes in the biomasses of (O) naked heterotrophic dinoflagellates (NHD) and (•) naked ciliates; averages of values for 0 and $10 \mathrm{~m}$. Cell volumes of each were estimated to be: $300 \mu^{3}$ for $\mathrm{NHD}<20 \mu \mathrm{m}$, $4800 \mu^{3}$ for $\mathrm{NHD} 20$ to $40 \mu \mathrm{m}, 12000 \mu^{3}$ for NHD $>40 \mu \mathrm{m}, 850 \mu \mathrm{m}^{3}$ for ciliates $<20 \mu \mathrm{m}$, and $16000 \mathrm{\mu m}^{3}$ for ciliates $>20 \mu \mathrm{m}$. A carbon/ volume conversion factor of $0.1 \mathrm{pg} \mathrm{C} \mu \mathrm{m}^{-3}$ was also assumed for all taxa

The grazing impact $\left(G I ; \mathrm{d}^{-1}\right)$ by these 2 dinoflagellates was calculated by

$$
G I=I_{\max }\left(N_{G D}+2.5 N_{G S}\right) /\left(K+N_{\text {prey }}\right),
$$

where $I_{\max }$ is the maximum ingestion rate for $G$ dominans ( 19.7 prey predator $\left.{ }^{-1} \mathrm{~d}^{-1}\right), K$ is the half saturation constant $\left(820 \mathrm{ml}^{-1}\right), N_{\text {prey }}, N_{\mathrm{GD}}, N_{\mathrm{GS}}$ are the initial abundances of naked autotrophic flagellates (20 to $40 \mu \mathrm{m}$; mainly composed of G. mikimotol), GDLP, and NHD $(>40 \mu \mathrm{m})$, respectively. The heterotrophic dinoflagellate grazing impact was relatively low (16 to $28 \%$ $\mathrm{d}^{-1}$ ) during the first half of the outbreak (26 to 29 July). It then increased to reach a maximum on 1 August $\left(55 \% \mathrm{~d}^{-1}\right)$. At this time the G. mikimotoi cells looked unhealthy and inactive, probably due to nutrient depletion (Ichimi et al. unpubl.), and low growth rates of $G$. mikimotoi (ca $0 \mathrm{~d}^{-1}$ ) were expected. Thus it is probable that along with the descent of senescent $G$. mikimotoi cells to the bottom, ingestion by NHD contributed significantly to the rapid decrease in the red tide populations from 1 to 2 August.

In conclusion, the naked heterotrophic dinoflagellates Gyrodinium dominans and $G$. spirale were released from food limitation following the outbreak of a Gymnodinium mikimotoi red tide. The naked heterotrophic dinoflagellate populations then rapidly increased and probably contributed to the disappearance of the red tide. On the other hand, ciliates did not respond to the red tide and did not seem to compete with the heterotrophic dinoflagellates. The notion that heterotrophic dinoflagellates control the fate of pri- mary producers of comparable size also suggests that the efficiency of carbon flow from the primary producers to larger consumers in higher trophic levels (such as copepods) is reduced by the activity of heterotrophic dinoflagellates.

Acknowledgements. We thank Dr S. Nagai for making his field data available, Dr R. Weisburd for his constructive comments and linguistic corrections, and $\mathrm{K}$. Ichimi and $\mathrm{H}$. Kobayashi for supporting the field sampling. This study was supported by Grant-in-Aid No. 05640720 from the Scientific Research Fund of the Ministry of Education, Science and Culture, Japan

\section{LITERATURE CITED}

Hansen PJ (1991) Quantitative importance and trophic role of heterotrophic dinoflagellates in a coastal pelagial food web. Mar Ecol Prog Ser 73:253-261

Hansen PJ (1992) Prey size selection, feeding rates and growth dynamics of heterotrophic dinoflagellates with special emphasis on Gyrodinium spirale. Mar Biol 114: $327-334$

Jacobson DM (1987) The ecology and feeding biology of thecate heterotrophic dinoflagellates. PhD thesis, Woods Hole Oceanographic Institution/Massachusetts Institute of Technology Joint Program

Jacobson DM, Anderson DM (1993) Growth and grazing rates of Protoperidinium hirobis Abé, a thecate heterotrophic dinoflagellate. J Plankton Res 15:723-736

Jeong HJ, Latz MI (1994) Growth and grazing rates of the heterotrophic dinoflagellates Protoperidinium spp. on red tide dinoflagellates Mar Ecol Prog Ser 106:173-185

Lessard EJ (1991) The trophic role of heterotrophic dinoflagellates in diverse marine environments. Mar microb Food Webs 5:49-58 
Nakamura Y, Fukami K, Sasaki S, Hiromi J (1994) Population dynamics of bacteria and heterotrophic nanoflagellates following the summer diatom bloom in the Seto Inland Sea. Bull Plankton Soc Japan $41: 1-8$

Nakamura Y, Sasaki S. Hiromi J, Fukami K (1993) Dynamics of picocyanobacteria in the Seto Inland Sea (Japan) during summer. Mar Ecol Prog Ser 96:117-124

Nakamura Y, Suzuki S, Hiromi J (1995) Growth and grazing of a naked heterotrophic dinoflagellate, Gyrodinium dominans. Aquat microb Ecol 9:157-164

Nakamura, Y, Umemori T (1991) Encystment of the red tide flagellate Chattonella antiqua (Raphidophyceae): cyst yield in batch cultures and cyst flux in the field. Mar Ecol Prog Ser 78:273-284

Nakamura Y, Yamazaki Y, Hiromi J (1992) Growth and grazing of a heterotrophic dinoflagellate, Gyrodinium domlnans, feeding on a red tide flagellate, Chattonella antiqua. Mar Ecol Prog Ser 82:275-279

Nöthig E, von Bodungen B (1989) Occurrence and vertical flux of faecal pellets of probably protozoan origin in the

This article was submitted to the editor southeastern Weddell Sea (Antarctica). Mar Ecol Prog Ser $56: 281-289$

Porter KG, Feig YS (1980) The use of DAPl for identifying and counting aquatic microflora. Limnol Oceanogr 25 . $943-948$

Sherr EB, Sherr BF, Fallon RD, Newell SY (1986) Small, aloricate cillates as a major component of the marine heterotrophic nanoplankton. Limnol Oceanogr 31:177-183

Smetacek $V$ (1981) The annual cycle of protozooplankton in the Kiel Bight. Mar Biol 63:1-11

Strom SL (1991) Growth and grazing rates of the herbivorous dinoflagellate Gymnodinium sp. from the open subarctic Pacific Ocean. Mar Ecol Prog Ser 78:103-113

Strom SL, Buskey EJ (1993) Feeding, growth, and behavior of the thecate heterotrophic dinoflagellate Oblea rotunda. Limnol Oceanogr 38:965-977

Verity PG, Stoecker DK, Sieracki ME, Burkill PH, Edwards ES, Tronzo CR (1993) Abundance, biomass and distribution of heterotrophic dinoflagellates during the North Atlantic spring bloom. Deep Sea Res II 40:227-244

Manuscript first received: January 10, 1995

Revised version accepted: March 20, 1995 